\title{
GROWTH MINDSET, INSTRUCTORS' SCAFFOLDING, DAN SELF- REGULATED LEARNING PADA PEMBELAJARAN JARAK JAUH SELAMA PANDEMI COVID-19
}

\author{
Yudith Bernadette Ayu Putri \& Lucia R. M. Royanto
}

Fakultas Psikologi, Universitas Indonesia, Kampus Baru UI Depok, Jawa Barat 16424, Indonesia

Korespondensi: yudith.bernadette@gmail.com

\section{GROWTH MINDSET, INSTRUCTORS' SCAFFOLDING, AND SELF- REGULATED LEARNING IN DISTANCE LEARNING DURING COVID-19 PANDEMIC}

\section{Abstract}

Distance learning has been regarded as an alternative learning method instead of the traditional face-to-face learning, especially during the COVID-19 pandemic. Distance learning accommodates a minimum amount of physical distance between students and teachers; hence, it is necessary for students to be competent in regulating themselves during their learning process. The purpose of this studyis to examine the correlation between growth mindset and instructors' scaffolding towards students' self-regulated learning, particularly during distance learning program where students-lecturer interaction is mediated through online channels. Participants were 387 undergraduatestudents from 10 Indonesian state universities. The result indicates that growth mindset and instructors' scaffolding significantly explained $26 \%$ variance of students' self-regulated learning, with intstructors' scaffolding being a stronger determinant than students' growth mindset. The study informs a potential strategy for lecturers to enhance student's self-regulated learning by developing instructors' scaffolding more than growth mindset during pandemic era.
Manuscript type: Original Research

Article history:

Received 24 August 2020

Received in revised form 19 September 2020

Accepted 1 February 2021

Available online 25 March 2021

\section{Keywords:}

distance learning

growth mindset

instructors' scaffolding

online learning

self-regulated learning

\begin{abstract}
Abstrak
Pembelajaran jarak jauh semakin banyak digunakan sebagai metode pembelajaran alternatif menggantikan metode belajar tradisional, terutama setelah pandemi COVID-19. Dalam praktiknya, mahasiswa dan dosen akan berjarak, sehingga peranan mahasiswa untuk menampilkan regulasi diri dalam proses belajar menjadi hal yang penting. Penelitian ini bertujuan untuk melihat pengaruh growth mindset dan instructors' scaffolding dalam meningkatkan self-regulated learning mahasiswa, terutama terkait interaksi antara dosen dan mahasiswa yang dimediasi melalui media daring. Subjek penelitian ini terdiri dari 387 mahasiswa sarjana yang tersebar dalam 10 universitas negeri di Indonesia. Hasil menunjukan bahwa growth mindset dan instructors' scaffolding secara signifikan memengaruhi self-regulated learning mahasiswa sebesar $26 \%$, di mana instructors' scaffolding menjadi determinan yang lebih kuat daripada growth mindset. Studi ini menginformasikan strategi bagi pendidik untuk melakukan intervensi yang lebih berfokus pada instructors' scaffolding daripada terkait growth mindset dalam membantu mahasiswa mengembangkan self-regulated learning.
\end{abstract}

Kata Kunci: growth mindset, instructors' scaffolding, pembelajaran jarak jauh, self-regulated learning

\section{Dampak dan Implikasi dalam Konteks Ulayat}

Pembelajaran jarak jauh merupakan hal baru bagi sistem pendidikan di Indonesia, sedangkan efektivitas implementasinya beragam dari satu negara ke negara lainnya. Penelitian ini menguji pengaruh faktor internal dan eksternal terhadap kemampuan kontrol diri mahasiswa Indonesia dalam mengikuti pembelajaran jarak jauh selama masa pandemi COVID-19. Dalam masa pandemi, mahasiswa dituntut untuk beradaptasi dengan metode pembelajaran jarak jauh yang membutuhkan kontrol diri yang baik. Hasil studi terhadap mahasiswa universitas negeri di Indonesia menunjukkan bahwa, dibandingkan dengan pengembangan pola pikir mahasiswa yang terbuka terhadap perubahan (growth mindset), dukungan dari dosen (scaffolding) merupakan faktor yang lebih penting dalam mengembangkan kontrol diri mahasiswa selama pembelajaran dilakukan jarak jauh. 


\section{PENDAHULUAN}

Semenjak pandemi COVID-19 di Indonesia, distance learning atau pembelajaran jarak jauh kian marak diandalkan sebagai metode pembelajaran untuk siswa dari berbagai jenjang. Dalam jangka waktu pendek, seluruh proses belajar-mengajar dialihkan menjadi pembelajaran jarak jauh. Hal ini menyebabkan seluruh pihak dalam proses pendidikan, baik pengajar, mahasiswa, maupun staf kesulitan untuk beradaptasi (Komite Penanganan COVID-19 dan Pemulihan Ekonomi Nasional, 2020). Meskipun demikian, sebenarnya pembelajaran jarak jauh sendiri bukan merupakan konsep baru, tetapi sudah menjadi bahasan dalam metode pembelajaran sejak tahun 1997 (Anderson \& Elloumi, 2004; Eom \& Ashill, 2016).

Pembelajaran jarak jauh dapat diartikan sebagai metode belajar yang mengandalkan jaringan internet sebagai alat bantu untuk mengakses materi, serta berinteraksi dengan dosen atau teman sekelas (Anderson \& Elloumi, 2004; Kauffman, 2015). Pembelajaran dengan metode ini tetap bertujuan untuk memberikan pengetahuan, mendorong proses belajar mahasiswa, dan mengembangkan diri setiap mahasiswa. Namun, pembelajaran jarak jauh biasanya digunakan pada mahasiswa usia 25-50 tahun karena sesuai dengan karakter dan kebutuhan (Moore \&Kearsley, 2005). Individu pada rentang usia tersebut memiliki kebutuhan akan proses pembelajaran yang lebih fleksibel. Metode pembelajaran yang lebih fleksibel memungkinkan keseimbangan untuk bekerja, belajar, dan mengurus keluarga. Di Indonesia, mahasiswa dan dosen pada jenjang pendidikan tinggi juga diketahui lebih mampu beradaptasi dengan metode pembelajaran jarak jauh (Herlina, 2020). Meskipun demikian, mahasiswa dan dosen tetap mengalami hambatan dalam memaksimalkan proses pembelajaran jarak jauh dan perlu melakukan pengembangan dalam penerapan metode pembelajaran jarak jauh, seperti mahasiswa dituntut untuk mampu belajar secara mandiri dan dosen dituntut untuk mengembangkan metode belajar yang efektif (Hendayana dkk., 2020). Oleh karena itu, penelitian ini akan berfokus untuk melihat kondisi mahasiswa pada jenjang perguruan tinggi ketika mengikuti pembelajaran jarak jauh.

Dalam menerapkan metode pembelajaran jarak jauh, sangat penting untuk memperhatikan karakter pelajar dan karakter pengajar. Kedua hal tersebut berbeda dengan karakter yang umumnya ditemukan dan dibutuhkan dalam metode pembelajaran tradisional (Blau dkk., 2020; Kauffman, 2015). Oleh karena itu, muncul tuntutan baru seperti dibutuhkannya kontrol diri dan usaha mahasiswa yang lebih besar, serta usaha pengajar untuk mencari metode yang tepat dalam membantu mahasiswa (Cho \& Jonassen, 2009; Kizilcec \& Halawa, 2015; Mullen \& Tallent- 
Runnels, 2006; Wong dkk., 2019). Penelitian mengenai growth mindset menyatakan bahwa mindset dapat memengaruhi mahasiswa dalam memandang seberapa besar usaha tersebut perlu dilakukan (Mrazek dkk., 2018). Oleh karena itu, penelitian ini akan membahas mengenai pengaruh karakter mahasiswa, meliputi kemampuan self-regulated learning dan growth mindset, serta karakter pengajar, yaitu kemampuan scaffolding yang memengaruhi proses belajar, terutama dalam pembelajaran jarak jauh.

\section{Self-Regulated Learning}

Dalam penerapan pembelajaran jarak jauh, terdapat berbagai tantangan yang dihadapi oleh mahasiswa maupun dosen. Kondisi berjarak antara dosen dengan mahasiswa mengakibatkan dibutuhkannya peran penting dari mahasiswa secara mandiri (Blau dkk., 2020; Kauffman, 2015). Mahasiswa perlu mengembangkan kemampuan self-regulated learning yang di dalamnya meliputi kedisiplinan diri, manajemen waktu, kemampuan berencana, serta kemampuan evaluasi diri yang baik (Azevedo dkk., 2010; Kauffman, 2015; Wong dkk., 2019). Kemampuan self-regulated learning pada mahasiswa, terutama dalam interaksi jarak jauh, dapat mendorong mahasiswa untuk lebih terlibat dalam aktivitas pembelajaran dan menghasilkan proses belajar yang lebih baik (Cho \& Jonassen, 2009; Wong dkk., 2019). Hal ini terjadi karena mahasiswa menjadi lebih terlibat dalam proses belajar dan dituntut untuk lebih bertanggung jawab terhadap proses belajarnya sendiri.

Self-regulated learning merupakan suatu proses individu dalam menghasilkan pikiran, perasaan, dan perilaku yang mengarah kepada orientasi pencapaian tujuan (Zimmerman, 2002). Self-regulated learning dipengaruhi oleh beberapa faktor, seperti kondisi demografis, kondisi pengajar, dan karakter mahasiswa (Cho \& Kim, 2013). Kondisi demografis yang memengaruhi meliputi usia, tingkat pendidikan, dan pengalaman mengikuti pembelajaran jarak jauh. Diketahui bahwa pelajar dijenjang yang lebih tinggi dan memiliki pengalaman mengikuti pembelajaran jarak jauh akan lebih mampu mengembangkan regulasi diri. Kondisi pengajar dan karakter mahasiswa berinteraksi untuk meningkatkan regulasi diri. Kondisi pengajar yang diketahui dapat memengaruhi adalah memberikan scaffolding (stimulus bertahap yang meningkat sesuai dengan kapasitas mahasiswa) dalam proses belajar (Cho \& Kim, 2013). Sementara itu, karakter mahasiswa yang memengaruhi adalah growth mindset, yaitu kepercayaan yang dimiliki untuk melakukan usahausaha dalam mencapai tujuan (Mrazek dkk., 2018).

Kebanyakan konsep self-regulated learning berfokus pada proses internal yang terjadi, tetapi beberapa penelitian lain mengaitkan faktor internal dengan faktor eksternal untuk 
memperoleh konteks yang lebih spesifik (Cho \& Jonassen, 2009). Cho dan Jonassen (2009) mengembangkan konsep self-regulated learning yang berfokus pada sejauh mana individu meregulasi diri dalam berinteraksi dengan orang lain. Konsep ini terdiri dari tiga faktor, yaitu afeksi atau motivasi, metakognisi, dan kognisi. Ketika individu melakukan usaha untuk membangun interaksi sosial, ketiga faktor tersebut berinteraksi secara dinamis menghasilkan perilaku yang mendorong tercapainya tujuan belajar. Faktor afeksi atau motivasi melibatkan aspek kesenangan, keyakinan diri, dan kekhawatiran. Faktor metakognisi melibatkan aspek perencanaan, monitoring, dan refleksi. Faktor kognisi melibatkan strategi-strategi yang dilakukan dalam membentuk interaksi yang tepat selama proses belajar.

\section{Instructors' Scaffolding}

Keberadaan instructors' scaffolding diketahui dapat meningkatkan kemampuan selfregulated learning pada mahasiswa, terutama dalam konteks membangun interaksi (Cho \& Kim, 2013). Dosen terbatas untuk melakukan observasi terhadap perilaku nonverbal mahasiswa dalam pembelajaran jarak jauh, akibatnya dosen kesulitan untuk menilai derajat pemahaman atau proses belajar mahasiswa langsung ketika materi diberikan (Kauffman, 2015). Hal ini menyebabkan dosen terhambat untuk menyesuaikan pemberian materi sesuai dengan pemahaman mahasiswa. Kondisi ini menuntut dosen untuk melakukan usaha berbeda dalam mendorong proses belajar yang maksimal pada mahasiswa. Usaha-usaha tertentu yang dilakukan dosen dalam rangka mendorong proses belajar mahasiswa disebut instructors' scaffolding (Cho \& Kim, 2013). Menurut Mullen dan Tallent-Runnels (2006), mahasiswa yang mengikuti pembelajaran jarak jauh lebih membutuhkan dukungan dari dosen untuk terlibat dalam proses belajar, terutama dalam aspek afeksi. Kontrol diri mahasiswa pada pembelajaran jarak jauh tidak hanya melibatkan usaha individu saja, tetapi juga memerlukan adanya kerja sama antara mahasiswa dengan dosen (Cho \& Kim, 2013).

Instructors' scaffolding yang dapat dilakukan dosen adalah mendorong mahasiswa untuk terlibat aktif dan melakukan interaksi dalam proses pembelajaran jarak jauh (Anderson \& Elloumi, 2004; Cho \& Cho, 2016; Cho \& Kim, 2013; Eom \& Ashill, 2016; Kauffman, 2015; Wong dkk., 2019). Interaksi yang dilakukan meliputi interaksi antara mahasiswa dengan konten pembelajaran, mahasiswa dengan mahasiswa, dan mahasiswa dengan dosen. Interaksi antara mahasiswa dengan konten pembelajaran, seperti membaca materi yang diberikan, mengerjakan tugas yang diberikan, atau mencari tahu informasi-informasi tambahan dalam rangka menambah pengetahuan mengenai materi. Interaksi antara mahasiswa dengan mahasiswa, seperti berdiskusi untuk mengerjakan tugas, 
bertanya ketika kurang memahami materi, memberikan tanggapan berupa pertanyaan atau komentar terhadap informasi yang diberikan mahasiswa lain, atau memberikan bantuan ketika mahasiswa lain membutuhkan. Kemudian, interaksi antara dosen dengan mahasiswa, seperti mahasiswa bertanya kepada dosen, merespons umpan balik yang diberikan dosen, atau memberikan umpan balik kepada dosen. Instructors' scaffolding dalam penelitian ini akan dilihat berdasarkan persepsi mahasiswa mengenai usaha-usaha yang dilakukan dosen selama pembelajaran jarak jauh.

\section{Growth Mindset}

Mahasiswa yang memiliki pandangan positif terkait usaha yang perlu dilakukan dalam mencapai tujuan belajar cenderung dapat mengembangkan self-regulated learning yang baik (Mrazek dkk., 2018). Pandangan positif terkait usaha tersebut dapat terlihat dari mindset seseorang. Mahasiswa yang memiliki growth mindset akan fokus pada proses belajar dibandingkan hasil, sehingga ketika menghadapi tantangan ia akan lebih bertahan untuk mencapai tujuan. Mindset sendiri diartikan sebagai sudut pandang yang digunakan individu terhadap dirinya sendiri yang akan memengaruhi bagaimana individu tersebut mengarahkan hidupnya (Bernecker \& Job, 2019; Dweck, 2017). Pandangan ini meliputi kecerdasan dan kepribadian seseorang.

Terdapat dua tipe mindset, yaitu fixed mindset dan growth mindset. Fixed mindset adalah keyakinan bahwa sifat dasar manusia menetap dan tidak dapat diubah, sedangkan growth mindset adalah keyakinan bahwa sifat dasar manusia dapat dibentuk dan diubah secara substansial (Bernecker \& Job, 2019). Individu dengan fixed mindset akan sibuk untuk membuktikan dan memvalidasi dirinya karena meyakini bahwa kecerdasan seseorang bersifat tetap dan ingin membuktikan bahwa kecerdasannya baik. Hal ini membuat individu dengan fixed mindset akan cenderung membuat penilaian negatif terhadap kegagalan, menampilkan efek negatif, dan ketidakberdayaan terhadap tantangan yang dihadapi. Di sisi lain, individu dengan growth mindset akan menampilkan perilaku yang lebih adaptif ketika dihadapkan pada tantangan karena mereka melihat kecerdasan adalah hal yang dapat ditingkatkan melalui usaha dan kegagalan adalah hasil dari strategi yang kurang tepat. Meskipun demikian, individu biasanya tidak hanya memegang satu tipe mindset saja, walaupun tetap ada kecenderungan pada tipe tertentu (Dweck, 2017). Mindset merupakan hal yang dapat diajarkan pada individu, terutama oleh orang tua sejak dini. 


\section{Tujuan Studi}

Berdasarkan uraian tersebut, peneliti melihat perlunya ada penelitian ilmiah yang memberikan masukan terhadap proses pembelajaran jarak jauh di Indonesia, terutama selama masa pandemi. Hasil penelitian ini dapat membantu memberikan arahan kepada pihak terkait untuk meningkatkan proses belajar mahasiswa dan mengurangi kerugian yang mungkin muncul. Oleh karena itu, penelitian ini menguji pengaruh instructors' scaffolding dan growth mindset terhadap self-regulated learning pada mahasiswa sarjana yang mengikuti kegiatan pembelajaran jarak jauh.

\section{METODE}

\section{Partisipan}

Partisipan dalam penelitian ini adalah mahasiswa yang berkuliah di 10 universitas negeri peringkat teratas di Indonesia berdasarkan hasil penilaian kualitas oleh Kementerian Riset, Teknologi, dan Perguruan Tinggi Indonesia (Biro Kerja Sama dan Komunikasi Publik dan Direktorat Jenderal Kelembagaan Ilmu Pengetahuan, Teknologi, dan Pendidikan Tinggi Kemenristekdikti, 2019). Penentuan partisipan menggunakan teknik aksidental yang disebarkan secara daring di media sosial.Kuesioner yang disebarkan sudah diuji secara etik oleh Komite Etik Penelitian Universitas Indonesia (No: 803/FPsi.Komite Etik/PDP.04.00/2020). Kuesioner juga dilengkapi dengan informed consent yang menyatakan kesediaan partisipan. Diperoleh data penelitian terhadap 387 partisipan mahasiswa dari 10 universitas, yaitu Institut Teknologi Bandung (11.62\%), Universitas Gadjah Mada (7.75\%), Institut Pertanian Bogor (8.78\%), Institut Teknologi Sepuluh Nopember (6.71\%), Universitas Indonesia (16.53\%), Universitas Diponegoro (8.26\%), Universitas Airlangga (12.40\%), Universitas Hasanuddin (6.20\%), Universitas Brawijaya (7.23\%), dan Universitas Padjadjaran (14.47\%). Rata-rata usia partisipan adalah 20.06 tahun $(S D=1.21)$ dengan jumlah partisipan perempuan $(73 \%)$ lebih banyak dibandingkan partisipan laki-laki.

\section{Desain}

Penelitian ini menggunakan pendekatan noneksperimental kuantitatif. Variabel yang akan digunakan adalah self-regulated learning sebagai variabel dependen, serta growth mindset sebagai variabel independen pertama dan instructors' scaffolding sebagai variabel independen kedua. 


\section{Prosedur}

Alat ukur yang akan digunakan diterjemahkan ke dalam Bahasa Indonesia dengan menggunakan pendekatan back translation. Peneliti terlebih dahulu menterjemahkan versi asli dari alat ukur ke Bahasa Indonesia. Versi terjemahkan kemudian diterjemahkan kembali ke Bahasa Inggris oleh anggota dari tim peneliti. Evaluasi dilakukan secara bersama-sama hingga tercapai kesepakatan atas versi terjemahan yang paling sesuai. Peneliti melakukan uji keterbacaan alat ukur terhadap 100 mahasiswa untuk menguji reliabilitas dan validitas sebelum menggunakan alat ukur tersebut. Uji coba alat ukur dilakukan dengan menyebarkan kuesioner daring melalui Instagram dan Whatsapp secara personal terhadap mahasiswa, organisasi mahasiswa, dan dosen-dosen pada universitas terkait. Mahasiswa yang terlibat diminta untuk menyetujui informed consent yang menyatakan kesediaan untuk berpartisipasi dalam penelitian. Partisipan terlebih dahulu diinformasikan mengenai haknya untuk mengundurkan diri tanpa konsekuensi apapun, serta seluruh data yang diperoleh hanya akan diolah secara kelompok dan bersifat rahasia. Setelah alat ukur teruji reliabel dan valid, peneliti menyebarkan kuesioner melalui metode yang sama dengan tahap uji coba alat ukur.

Untuk menguji hipotesis, peneliti menggunakan kelompok sampel berbeda dengan kelompok uji coba alat ukur. Mahasiswa yang terlibat dalam studi ini seluruhnya merupakan mahasiswa aktif di 10 universitas sasaran dan mengikuti kegiatan pembelajaran jarak jauh minimal 3 bulan sebelum mengisi kuesioner terkait.

\section{Instrumen}

Alat ukur yang digunakan dalam penelitian ini adalah Online Self-Regulated Learning Inventory (OSRLI), Implicit Theory Measures, dan Instructors' Use of Scaffolding for Interactions.

Online Self-regulated Learning Inventory (OSRLI) pertama kali dikembangkan oleh Cho dan Jonassen (2009) untuk mengukur self-regulated learning mahasiswa dengan mengaitkan proses internal dan eksternal pada mahasiswa yang mengikuti pembelajaran jarak jauh. Alat ukur tersebut terdiri dari dua dimensi, yaitu affect/motivation scaledaninteraction strategies scale. Affect/motivation scaleterdiri dari empat subdimensi, yaitu enjoyment of human interaction, concern for interaction with student, self-efficacy for interaction with instructors, dan self-efficacy for contributing to the online community. Interaction strategies scale terdiri dari tiga subdimensi, yaitu writing strategies, responding strategies, dan reflection strategies. Alat ukur asli terdiri dari 28 butir pernyataan dengan bobot yang berbeda pada setiap subdimensi dan didominasi oleh butir 
pernyataan dari subdimensi enjoyment of human interaction (7 butir pernyataan), sedangkan tiga subdimensi lainnya terdiri dari 3-4 butir. Seluruh subdimensi diukur menggunakan skala Likert dengan rentang angka 1-6 (1 = "Sangat Tidak Sesuai/Tidak Yakin Sama Sekali"; 6 = "Sangat Sesuai/Sangat Yakin"). Subdimensi writing strategies, responding strategies, dan reflection strategies diukur menggunakan skala Likert dengan rentang angka 1-6 (1 = "Tidak Pernah"; 6 = “Selalu”).

Pada penelitian ini, sebanyak sembilan butir pernyataan dihapus atas dasar pertimbangan kualitatif pada bobot butir pernyataan yang tidak seimbang, sehingga total butirnya ialah 19 butir. Koefisien reliabilitas untuk affect/motivation scale memiliki nilai Cronbach's Alpha sebesar .783 dan interaction strategies scale sebesar .773. Seluruh butir alat ukur ini memiliki corrected itemtotal correlation berkisar antara .386 hingga .660 .

Implicit Theory Measures dikembangkan oleh Dweck dkk. (1995) digunakan untuk mengukur variabel mindset. Implicit Theory Measures memiliki tiga domain untuk melihat pandangan terkait kecerdasan, moral, dan dunia yang terdiri dari tiga butir pada setiap domain. Dalam proses pengukuran, ketiga domain dapat digunakan secara terpisah sesuai dengan kebutuhan penelitian. Oleh karena itu, penelitian ini hanya akan menggunakan domain kecerdasan sesuai dengan konteks penelitian. Tiga butir pada domain kecerdasan diterjemahkan sesuai dengan jumlah butir pada alat ukur aslinya. Skala yang digunakan dalam alat ukur ini adalah skala Likert dengan rentang angka 1-6 (1 = "Sangat Setuju”; 6 = "Sangat Tidak Setuju”). Koefisien reliabilitas alat ukur ini memiliki nilai Cronbach's Alpha sebesar .812 dan memiliki corrected item-total correlation berkisar antara .587 hingga .724 .

Instructors' Use of Scaffolding for Interactions dikembangkan oleh Cho dan Kim (2013) dan memiliki 10 butir pernyataan. Alat ukur tersebut mengukur persepsi mahasiswa terhadap penggunaan metode scaffolding yang diterapkan dosen selama pembelajaran jarak jauh. Skala yang digunakan adalah skala Likert dengan rentang angka 1-6 (1 = "Sangat Tidak Sesuai"; 6 = "Sangat Sesuai"). Koefisien reliabilitas alat ukur ini memiliki nilai Cronbach's Alpha sebesar .861 dan memiliki nilai corrected item-total correlation berkisar antara .410 hingga .737 .

\section{Teknik Analisis}

Seluruh data yang terkumpul akan diolah menggunakan teknik analisis regresi berganda untuk melihat pengaruh dari dua variabel independen terhadap satu variabel dependen (Field, 2013). 


\section{ANALISIS DAN HASIL}

\section{Korelasi Antar Variabel}

Tabel 1 merangkum matriks korelasi antar variabel penelitian. Sebagaimana ditunjukkan dalam tabel, self-regulated learning memiliki korelasi yang signifikan, baik dengan mindset maupun instructors' scaffolding.

Tabel 1.

Matriks Korelasi Antar Variabel

\begin{tabular}{llllll}
\hline Dimensi & $\boldsymbol{M}$ & $\boldsymbol{S D}$ & $\mathbf{1}$ & $\mathbf{2}$ & $\mathbf{3}$ \\
\hline (1) Mindset & 11.54 & 3.28 &. & & \\
(2) Instructors' Scaffolding & 44.17 & 7.73 & .038 &. & \\
(3) Self-regulated learning & 86.94 & 11.48 & $.10^{*}$ & $.51^{* *}$ & . \\
\hline
\end{tabular}

Catatan: * Signifikan pada level .05; ** = Signifikan pada level .001

\section{Uji Asumsi}

Peneliti melakukan uji asumsi terlebih dahulu terhadap data yang didapatkan $(N=387)$. Data penelitian ini diketahui tidak memiliki outlier, tidak memiliki kondisi multicollinearity, memenuhi asumsi independent errors, berdistribusi normal, memenuhi asumsi homoscedasticity, dan memiliki hubungan linear. Dengan demikian, seluruh data yang diperoleh dapat diolah menggunakan analisis regresi berganda.

\section{Pengaruh Growth Mindset dan Instructors' Scaffolding Terhadap Self-regulated Learning}

Hasil pengujian analisis regresi berganda menunjukan bahwa growth mindset $(M=11.54$; $S D=3.28)$ dan instructors' scaffolding $(M=44.17 ; S D=7.73)$ secara signifikan $(F(2,384)=$ 68.02, $p<.05)$ berkontribusi terhadap self-regulated learning $(M=86.94 ; S D=11.48)$ dengan nilai $R^{2}$ sebesar 26 (lihat Tabel 2). Dengan demikian, dapat dikatakan bahwa sebesar 26\% varians growth mindset dan instructors' scaffolding dapat memengaruhi self-regulated learning pada mahasiswa yang mengikuti pembelajaran jarak jauh. Jika melihat dari nilai standardized coefficients (Tabel 2), diketahui bahwa kontribusi relatif instructors' scaffolding lebih besar dibandingkan peran growth mindset. 
Tabel 2.

Hasil Perhitungan Koefisien Regresi

\begin{tabular}{lcccc}
\hline \multirow{2}{*}{ Model } & \multicolumn{2}{c}{ Unstandardized Coefficients } & Standardized Coefficients & \multirow{2}{*}{ Sig. } \\
\cline { 2 - 4 } & $\boldsymbol{B}$ & Std. Error & Beta & $.000^{*}$ \\
(Constant) & 50.671 & 3.362 & & .059 \\
Mindset & .292 & .154 & .083 & $.000^{*}$ \\
Instructors' Scaffolding & .745 & .065 & .501 & \\
\hline
\end{tabular}

Catatan: * Signifikan pada level .05

\section{DISKUSI}

Penelitian ini menunjukkan bahwa growth mindset dan instructors' scaffolding memengaruhi kemampuan self-regulated learning dalam konteks interaksi selama proses pembelajaran jarak jauh. Hal ini menggambarkan bahwa apabila growth mindset dikembangkan pada mahasiswa dan dosen memberikan scaffolding yang tepat, maka mahasiswa akan lebih mampu meningkatkan kemampuan self-regulated learning pada konteks interaksi sebesar $26 \%$.

Hasil penelitian ini sejalan dengan studi yang dilakukan oleh Mrazek dkk. (2018) yang menunjukkan bahwa growth mindset memiliki pengaruh dalam meningkatkan kemampuan selfregulated learning mahasiswa. Bedford (2017) menemukan bahwa dengan mengajarkan mahasiswa mengenai kecerdasan dan cara mengembangkannya, maka mahasiswa dapat meningkatkan selfefficacy dan self-regulation. Self-regulated learning juga dapat dipengaruhi oleh instructors' scaffolding, terutama dalam konteks pembelajaran jarak jauh (Anderson \& Elloumi, 2004; Cho \& Cho, 2016; Cho \& Kim, 2013; Eom \& Ashill, 2016; Kauffman, 2015; Mullen \& Tallent-Runnels, 2006; Wong dkk., 2019).

Berdasarkan hasil penelitian ini, peran instructors' scaffolding lebih besar dalam memengaruhi self-regulated learning mahasiswa dibandingkan growth mindset ketika melakukan interaksi dalam pembelajaran jarak jauh. Hal ini mungkin disebabkan karena selama masa pandemi yang tidak menentu, mahasiswa lebih membutuhkan bantuan orang lain, dalam hal ini dosen, untuk membantu proses adaptasi mahasiswa terkait proses belajar yang baru. Kondisi ini sejalan dengan penelitian terdahulu yang menyatakan bahwa interaksi antara mahasiswa dengan lingkungan sosialnya menjadi hal yang utama dalam pembelajaran jarak jauh (Cho \& Jonassen, 2009; Wong dkk., 2019), sehingga keberadaan dosen yang membantu proses interaksi dapat memberikan dampak lebih signifikan terhadap regulasi mahasiswa dibandingkan proses internal mahasiswa itu sendiri. Menurut Cho dan Summers (2012), sebesar 36.5\% tugas dan kegiatan yang diikuti mahasiswa dalam pembelajaran jarak jauh membutuhkan interaksi antara mahasiswa dengan 
lingkungan sosialnya. Oleh karena itu, peran dosen untuk membantu proses belajar mahasiswa dalam masa adaptasi ini secara signifikan diperlukan.

Hasil penelitian ini juga menjelaskan bahwa meningkatkan growth mindset dan instructors' scaffolding dapat meningkatkan self-regulated learning pula .Self-regulated learning sendiri dibutuhkan mahasiswa, terutama dalam pembelajaran jarak jauh. Apabila mahasiswa tidak mampu atau terhambat dalam mengembangkan kemampuan tersebut, maka mahasiswa mungkin sulit untuk terlibat aktif, tidak mampu mengikuti proses belajar, dan sulit untuk mencapai tujuan pembelajaran (Cho \& Jonassen, 2009; Wong, dkk., 2019).

Terdapat beberapa hal yang perlu diperhatikan dalam penelitian ini. Pertama, sampel yang digunakan pada penelitian ini terbatas hanya pada 10 universitas negeri di Indonesia. Hal ini menyebabkan hasil penelitian kurang dapat digeneralisasikan pada mahasiswa dari universitas negeri lain maupun universitas swasta atau politeknik yang kemungkinan besar memiliki karakteristik berbeda. Kedua, penelitian ini tidak melihat dampak langsung terhadap hasil belajar mahasiswa, melainkan hanya melihat kondisi self-regulated learning mahasiswa. Dengan demikian, temuan dalam penelitian ini memiliki keterbatasan untuk melihat dampak langsung terhadap pencapaian mahasiswa. Ketiga, hubungan kausal yang ditemukan dalam penelitian ini tidak dapat langsung disimpulkan karena tidak menggunakan studi longitudinal.

\section{SIMPULAN DAN SARAN}

\section{Simpulan}

Penelitian ini menunjukan bahwa growth mindset dan instructors' scaffolding berpengaruh secara signifikan terhadap peningkatan self-regulated learning mahasiswa dalam melakukan interaksi selama mengikuti pembelajaran jarak jauh. Pengaruh instructors' scaffolding diketahui lebih besar dalam meningkatkan self-regulated learning pada interaksi jarak jauh dibandingkan pengaruh growth mindset.

\section{Saran Teoretis}

Penelitian selanjutnya dapat memperluas populasi penelitian agar dapat melihat kondisi mahasiswa jenjang sarjana di Indonesia secara keseluruhan. Menurut Wong dkk. (2019), kondisi self-regulated learning yang tepat dapat mendorong mahasiswa untuk aktif dalam proses belajar dan mendapatkan hasil belajar yang lebih baik, terutama dalam proses pembelajaran jarak jauh. 
Dengan demikian, penelitian selanjutnya dapat menambahkan variabel untuk mengukur hasil pembelajaran mahasiswa. Di sisi lain, konsep self-regulated learningyang berfokus pada faktor internal dan eksternal merupakan konsep yang mampu menjelaskan kondisi regulasi individu pada konteks pembelajaran jarak jauh (Cho \& Jonassen, 2009; Cho \& Summers, 2012). Namun, belum banyak penelitian yang menggunakan konsep ini, sehingga diperlukan penelitian lebih lanjut mengenai peranan self-regulated learning yang berfokus pada interaksi manusia. Penelitian selanjutnya juga dapat mengaitkan variabel usia dan jenis kelamin untuk melihat dampak terhadap pembelajaran jarak jauh atau menambahkan variabel lain yang dapat memengaruhi pencapaian mahasiswa.

\section{Saran Praktis}

Berdasarkan hasil penelitian, dosen dapat melakukan intervensi terkait instructors' scaffolding untuk dapat meningkatkan regulasi diri pada mahasiswa dalam rangka mencapai tujuan pembelajaran. Metode scaffolding yang dapat dilakukan dosen adalah memberikan respons positif terhadap komentar mahasiswa, menyediakan jadwal untuk mahasiswa berinteraksi dengan rekan dan dosen, dosen mendorong mahasiswa untuk bertanya atau memberikan pendapat, dan sebagainya (Cho \& Cho, 2016; Cho \& Kim, 2013). Monitoring penerapan instructors' scaffolding juga dapat dilakukan dengan mengevaluasi perkembangan interaksi yang dilakukan oleh mahasiswa, seperti melihat keaktifan mahasiswa atau melihat respons yang diberikan mahasiswa.

Penelitian ini juga dapat menunjukkan fenomena yang khas dalam konteks Indonesia terutama pada mahasiswa di universitas negeri, di mana proses belajar mahasiswa lebih bergantung kepada faktor eksternal atau keterlibatan dosen. Meskipun demikian, mahasiswa tetap perlu menyadari bahwa dirinya juga memiliki peran terhadap proses pembelajaran. Mahasiswa perlu mengembangkan growth mindset dengan cara fokus terhadap proses dibandingkan hanya pada hasil, mengembangkan sudut pandang bahwa perlu melakukan usaha agar dapat mencapai hasil belajar tertentu, dan mengembangkan pandangan bahwa kegagalan adalah proses belajar yang harus dilalui. Usaha yang dilakukan didasari atas keinginan dan kebutuhan diri sendiri dalam memahami materi pembelajaran. Hal ini dapat mendorong mahasiswa untuk lebih mandiri dan bertanggung jawab terhadap pencapaian belajarnya dibandingkan hanya bergantung kepada dosen untuk memberikan scaffolding. 


\section{REFERENSI}

Anderson, T., \& Elloumi, F. (2004). Theory and practice of online learning. Athabasca University.

Azevedo, R., Moos, D., Johnson, A., \& Chauncey, A. (2010). Measuring cognitive and metacognitive regulatory processes during hypermedia learning: Issues and challenges. Educational Psychologist, 45(4), 210-223. https://doi.org/10.1080/00461520.2010.515934

Bedford, S. (2017). Growth mindset and motivation: A study into secondary school science learning. Research Papers In Education, 32(4), 424-443. https://doi.org/10.1080/02671522.2017.1318809

Bernecker, K., \& Job, V. (2019). Mindset theory. Social Psychology In Action, 179-191. https://doi.org/10.1007/978-3-030-13788-5_12

Biro Kerja Sama dan Komunikasi Publik dan Direktorat Jenderal Kelembagaan Ilmu Pengetahuan, Teknologi, dan Pendidikan Tinggi Kemenristekdikti. (2019, Agustus 16). Menristekdikti umumkan klasterisasi perguruan tinggi Indonesia 2019, fokuskan hasil dari perguruan tinggi. https://www.ristekbrin.go.id/menristekdikti-umumkan-klasterisasi-perguruan-tinggiindonesia-2019-fokuskan-hasil-dari-perguruan-

tinggi/\#: :text=Pada\%20tahun\%202019\%2C\%20Kemenristekdikti\%20mengeluarkan,terdiri $\%$ 20dari\%20Politeknik\%20dan\%20Akademi.

Blau, I., Shamir-Inbal, T., \& Avdiel, O. (2020). How does the pedagogical design of a technologyenhanced collaborative academic course promote digital literacies, self-regulated learning, and perceived learning of students? The Internet And Higher Education, 45, 1-35. https://doi.org/10.1016/j.iheduc.2019.100722

Cho, M., \& Cho, Y. (2016). Online instructors' use of scaffolding strategies to promote interactions: A scale development study. International Review of Research in Open and Distributed Learning, 17(6), 109-120.https://doi.org/10.19173/irrodl.v17i6.2816

Cho, M., \& Jonassen, D. (2009). Development of the human interaction dimension of the Self-Regulated Learning Questionnaire in asynchronous online learning environments. Educational Psychology, 29(1), 117-138. https://doi.org/10.1080/01443410802516934

Cho, M., \& Kim, B. (2013). Students' self-regulated learning for interaction with others in online learning environments. The Internet and Higher Education, 17, 69-75. https://doi.org/10.1016/j.iheduc.2012.11.001 
Cho, M. H., \& Summers, J. (2012). Factor validity of the motivated strategies for learning questionnaire (MSLQ) in asynchronous online learning environments (AOLE). Journal of Interactive Learning Research, 23(1), 5-28.

Dweck, C. (2017). Mindset (2nd ed.). Constable \& Robinson Ltd.

Dweck, C., Chiu, C., \& Hong, Y. (1995). Implicit theories and their role in judgments and reactions: A word from two perspectives. Psychological Inquiry, 6(4), 267-285. https://doi.org/10.1207/s15327965pli0604_1

Eom, S., \& Ashill, N. (2016). The determinants of students' perceived learning outcomes and satisfaction in university online education: An update*. Decision Sciences Journal of Innovative Education, 14(2), 185-215. https://doi.org/10.1111/dsji.12097

Field, A. (2013). Discovering statistics using IBM SPSS Statistics. Sage Publications.

Hendayana, Y., Atmaja, D., Handini, D., Hidayat, F., Herlina, N., Nurita, N., Sari R., Yunanto, D., Herlina, S., Fajri, M. S., Priandono, T. E., Larasati, C., Satria, G. E., Rouf, M. F., \& Boediono, S. (2020). Buku pendidikan tinggi di masa pandemi COVID-19. Direktorat Jenderal Pendidikan Tinggi Kementerian Pendidikan dan Kebudayaan RI. https://dikti.kemdikbud.go.id/wp-content/uploads/2020/11/Buku-3_Pengabdian-PT.pdf

Herlina, N. (2020). Strategi dan kebijakan Ditjen Dikti terhadap keberlanjutan pendidikan tinggi di Indonesia dalam hadapi pandemi Covid-19. https://dikti.kemdikbud.go.id/kabardikti/kabar/strategi-dan-kebijakan-ditjen-dikti-terhadap-keberlanjutan-pendidikan-tinggi-diindonesia-dalam-hadapi-pandemi-covid-19/\#

Kauffman, H. (2015). A review of predictive factors of student success in and satisfaction with online learning. Research in Learning Technology, 23(1), 1-13. https://doi.org/10.3402/rlt.v23.26507

Kizilcec, R., \& Halawa, S. (2015). Attrition and achievement gaps in online learning. Proceedings of The Second (2015) ACM Conference On Learning@Scale-L@S '15. ACM Digital Library. https://doi.org/10.1145/2724660.2724680

Komite Penanganan COVID-19 dan Pemulihan Ekonomi Nasional. (2020, Agustus 8). Penyesuaian kebijakan pembelajaran di masa pandemi COVID-19 - guru dan siswa. https://covid19.go.id/p/guru-dan-siswa/penyesuaian-kebijakan-pembelajaran-di-masapandemi-covid-19.

Moore, M. G., \& Kearsley, G. (2005). Distance education: A systems view of online learning. Wadsworth. 
Mullen, G. E., \& Tallent-Runnels, M. K. (2006). Student outcomes and perceptions of instructors demands and support in online and traditional classrooms. The Internet and Higher Education, 9(4), 257-266. https://doi.org/10.1016/j.iheduc.2006.08.005

Mrazek, A., Ihm, E., Molden, D., Mrazek, M., Zedelius, C., \& Schooler, J. (2018). Expanding minds: Growth mindsets of self-regulated learning and the influences on effort and perseverance. Journal of Experimental Social Psychology, 79, 164-180. https://doi.org/10.1016/j.jesp.2018.07.003

Wong, J., Khalil, M., Baars, M., de Koning, B., \& Paas, F. (2019). Exploring sequences of learner activities in relation to self-regulated learning in a massive open online course. Computers \& Education, 140(103595), 1-14.https://doi.org/10.1016/j.compedu.2019.103595

Zimmerman, B. J. (2002). Becoming a self-regulated learner: An overview. Theory Into Practice, 41(2), 64-70. https://doi.org/10.1207/s15430421tip4102_2 